Krzysztof Arcimowicz

Uniwersytet w Białymstoku

\title{
Kryzys męskości czy szansa dla mężczyzn? Przegląd problematyki badań
}

\section{Wprowadzenie}

Artykuł chciałbym zacząć od pewnej refleksji natury ogólnej. Termin „kryzys” jest obecnie jednym z najczęściej używanych. Stosuje się go w odniesieniu do wielu dziedzin życia i na dobre zadomowił się w różnych dyscyplinach nauki. Można wręcz odnieść wrażenie, że świat pogrążony jest w wielkim, niespotykanym nigdy wcześniej kryzysie. Powszechne posługiwanie się określeniem kryzys powoduje, że część ludzi uważa, że kiedyś świat był lepszy, bardziej sprawiedliwy, pozbawiony kryzysów. Jak sądzę, ta iluzja lepszego minionego świata może wpływać na negatywną ocenę przemian męskości, kobiecości, seksualności i rodziny, które dokonują się we współczesnych społeczeństwach.

Zagadnieniem kryzysu męskości zajmują się dziś przedstawiciele bardzo różnych dyscyplin wiedzy: socjolodzy, psycholodzy, pedagodzy, antropolodzy kultury, historycy i filozofowie. Autorki i autorzy piszący o kryzysie męskości mają różny światopogląd, odwołują się do różnych teorii i odmiennie wartościują przemiany społeczne związane z emancypacją kobiet. To wszystko sprawia, że na kryzys męskości patrzy się z odmiennych punktów widzenia, przedstawia się różne wskaźniki owego kryzysu i łączy się go z różnorodnymi zjawiskami. W Polsce zaczęto szerzej pisać o kryzysie tożsamości męskiej na początku XXI wieku. Ważnym przyczynkiem do dyskusji była książka Zbyszko Melosika zatytułowana Kryzys męskości w kulturze wspótczesnej. Melosik (2002, s. 7) podaje, że na początku XXI wieku, wpisując hasło „kryzys męskości” w przeglądarce Google, otrzymywaliśmy około 20 tysięcy adresów internetowych. W październiku 2014 roku do terminu „kryzys męskości” odnosiło się już ponad 90 tysięcy adresów w języku polskim i blisko milion siedemset tysięcy w języku angielskim ${ }^{1}$. Można zatem stwierdzić, iż zagadnienie kryzysu męskości wzbudza zainteresowanie coraz większej liczby

1 Stan z 8 października 2014 roku. Wpisywane przeze mnie $\mathrm{w}$ przeglądarce hasło $\mathrm{w}$ języku angielskim to crisis of masculinity. 
naukowców i publicystów, choć moim zdaniem wiedza na temat kryzysu męskości w społeczeństwie polskim jest niewielka².

Celem artykułu jest scharakteryzowanie różnych sposobów rozumienia kryzysu męskości w literaturze przedmiotu. Odwołam się głównie do publikacji naukowych, ale w celu lepszego naświetlenia zagadnienia będę sięgał również do literatury popularnonaukowej i artykułów internetowych. Ponadto chciałbym przedstawić własne stanowisko dotyczące kryzysu męskości.

Termin „kryzys męskości” w odniesieniu do przemian relacji między kobietami i mężczyznami, jak też samej kategorii męskości, zaczął być używany powszechnie przez zachodnich badaczy w ostatniej dekadzie minionego stulecia, ale o problemach tożsamościowych mężczyzn pisano znacznie wcześniej. Część książek i artykułów powstałych w latach 70. i 80. XX wieku, mimo że nie występuje w nich określenie „kryzys męskości”, owego kryzysu w dużym stopniu dotyczy. Dlatego w niniejszym artykule wszędzie, gdzie jest to konieczne, odwołuję się do tych publikacji.

Można powiedzieć, że obecnie w Polsce, podobnie jak w innych krajach należących do kręgu kultury Zachodu, istnieją dwa konkurujące ze sobą paradygmaty męskości. Tradycyjny paradygmat ujmuje męskość jako dominację i specjalizację w określonych dziedzinach. Opiera się na dualizmie ról płciowych, asymetryczności cech męskich i kobiecych. Wymaga od mężczyzny podporządkowywania sobie innych mężczyzn, kobiet i dzieci. Oznacza przymus tłumienia uczuć i emocji ${ }^{3}$. Nowy paradygmat męskości akcentuje równość oraz partnerstwo mężczyzn i kobiet, uznając te wartości za fundamentalne w tworzeniu nowego ładu społecznego. Zawiera koncepcje androgyniczności i samorealizacji rozumiane jako dążenie do pełni człowieczeństwa. Ten paradygmat pozwala mężczyźnie na eksponowanie zarówno cech męskich, jak i kobiecych. Jego dewizą życiową staje się współdziałanie, a nie dominacja, jest on partnerem dla kobiet i dzieci. Nowa wersja męskości - w przeciwieństwie do paradygmatu tradycyjnego - nie upośledza innych niż heteroseksualna tożsamości seksualnych (zob. Arcimowicz 2003, s. 25-27). Patriarchalna wizja i nowoczesna wizja męskości toczą walkę o nadanie danej wersji statusu „prawdy”. Jednak w rzeczywistości niewielu mężczyzn realizuje w swoim życiu wszystkie nakazy zawarte w imperatywie patriarchalnym. Stosunkowo niewielką grupę stanowią mężczyźni opowiadający się za wszystkimi postulatami nowoczesnej wizji męskości. Zdecydowana większość mężczyzn we współczesnych społeczeństwach Zachodu realizuje w swoim życiu wartości i wzory zachowań stanowiące kontaminację elementów pochodzących

2 Tezę tę formułuję na podstawie rozmów przeprowadzonych ze studentkami i studentami kilku polskich uczelni wyższych podczas prowadzonych przeze mnie seminariów magisterskich i licencjackich oraz zajęć z zakresu antropologii kultury i socjologii kultury.

3 Tradycyjny paradygmat męskości w dużym stopniu pokrywa się z wersją męskości hegemonicznej opisaną przez australijską socjolożkę Raewyn Connell (1995, s. 71-86). 
z patriarchalnej i nowoczesnej wersji męskości ${ }^{4}$, przy czym nasilenie cech tradycyjnych i charakterystycznych dla nowego modelu może być różne - z przewagą jednej bądź drugiej opcji (Arcimowicz 2013, s. 173-179).

Jak sądzę, różne ujęcia kryzysu męskości wyrastają z dwóch odmiennych wizji męskości, choć w przypadku niektórych stanowisk widać krzyżowanie się dwóch koncepcji mężczyzny.

\section{Sposoby rozumienia kryzysu męskości}

Pierwsze stanowisko zakłada, że kryzys męskości pojawił się w związku z emancypacją kobiet, której efektem jest słabnięcie modelu męskości tradycyjnej. Wychodzi się tu z założenia, że męskość tradycyjna/patriarchalna związana z dominacją mężczyzn nad kobietami w społeczeństwie jest kategorią ahistoryczną, której nie można (re)negocjować. Tradycyjny paradygmat męskości akcentujący specjalizację kobiet i mężczyzn w określonych dziedzinach postrzega się jako model przejrzysty i najlepszy. Robert Bly uważa, że przemiany tradycyjnego modelu męskości spiętrzyły trudności w relacjach między kobietami i mężczyznami. Próby odejścia od tradycyjnego modelu są interpretowane $w$ kategoriach zagrożenia ładu społecznego (Bly 1993, s. 11-39). Zdaniem konserwatywnych autorów opierających swoje tezy na esencjalizmie biologicznym emancypacja kobiet przyczynia się do mnożenia problemów związanych z intymnymi relacjami między płciami, a także podziałem ról w rodzinie (zob. Bly 1993; Clark 1994; Dobson 1994).

W latach 60. i 70. XX wieku rozwój feminizmu w Stanach Zjednoczonych i w Europie Zachodniej przyczynił się do osłabienia tradycyjnego paradygmatu męskości i zwiększenia społecznych praw kobiet. Ruch feministyczny podjął ostrą krytykę traktowania różnic biologicznych jako podstawowego kryterium deprecjonowania płci żeńskiej i dowartościowania płci męskiej. Kobiety zyskały wiele przywilejów, wcześniej dostępnych tylko mężczyznom. Jednak w latach 80. minionego stulecia nastąpił silny kontratak na prawa kobiet, tak zwany backlash, czyli próba odebrania zwycięstw, jakie osiągnął feminizm. Susan Faludi (1992, s. 56-92) uważa, że jest to zjawisko w dużej mierze zakamuflowane. W Stanach Zjednoczonych, a następnie w innych krajach, pojawiło się wiele ruchów społecznych i organizacji głoszących hasła odbudowy autorytetu ojców w rodzinach i przywrócenia synom wzorca tradycyjnej męskości, jak również hasła antyfeministyczne. Pojawiły się też głosy sugerujące, że złe położenie kobiet jest skutkiem feminizmu. Zdaniem Faludi (1992) w środkach masowego przekazu przekręca się prawdę i fałszuje fakty, dając do zrozumienia, że działania, które doprowadziły do poprawy sytuacji kobiet, tak naprawdę tę sytuację pogorszyły. Według amerykańskiej autorki jednym z głównych celów backlashu jest wepchnięcie kobiet $\mathrm{z}$ powrotem $\mathrm{w}$ ich tradycyjne role.

4 Należy też zdawać sobie sprawę, że podobne zjawisko występuje na poziomie makro, to znaczy, że różne społeczeństwa odznaczają się różnym stopniem patriarchalności (zob. Malinowska 2002; Walby 1990). 
Konserwatywny ruch mężczyzn zawiązany w Stanach Zjednoczonych jest stowarzyszeniem wrogów emancypacji kobiet i homoseksualistów ${ }^{5}$. Czołową postacią tej organizacji był Robert Bly. Jedną z form przywrócenia mężczyznom utraconej „prawdziwej” męskości i siły psychicznej było organizowanie obozów, które odbywały się w ośrodkach wypoczynkowych. Spotkania te miały służyć wskrzeszeniu dzikich mężczyzn. Uczestnicy budowali szałasy, grali na bębnach, wydobywali z siebie dzikie okrzyki, a wszystko to miało pomóc w odbudowaniu męskiej tożsamości (por. Faludi 1992, s. 343-344).

Inną grupą starającą się odbudować dawną siłę tradycyjnego modelu męskości i przywrócić dymorfizm ról płciowych są Wierni Przyrzeczeniu (Promise Keepers). W 1996 roku konferencje w dwudziestu dwu miastach amerykańskich ściągnęły ponad milion uczestników. W październiku 1995 roku wielkim wydarzeniem stała się milionowa manifestacja mężczyzn na waszyngtońskim Mallu. Organizacja kładzie nacisk na specyficzną rolę mężczyzny, który powinien kierować rodziną i nie pozwalać, by tę rolę przejęły kobiety (Peterey-Mroczkowska 1998, s. 82-91).

W drugim podejściu łączy się kryzys męskości z problemami tożsamościowymi współczesnych mężczyzn, ale zdaniem badaczy owe problemy nie wynikają z emancypacji kobiet, lecz w największym stopniu są pochodną patriarchalnego modelu męskości. Psycholog Roger Horrocks w książce Masculinity in Crisis (1994) twierdzi, że jeśli spora grupa mężczyzn czuje się nieszczęśliwa, wycofuje się z życia społecznego, nie daje sobie rady z codziennymi problemami, unika odpowiedzialności, a ponadto okazuje agresję sobie nawzajem i kobietom, to można ją uznać za cierpiącą na kryzys męskości. Należy jednak podkreślić, że Horrocks twierdzi, że to męskość patriarchalna, męskość w stylu macho w największym stopniu ogranicza i okalecza mężczyzn. Jego zdaniem mężczyźni powinni porzucić patriarchalny stosunek do kobiet, a także na nowo przemyśleć swoją męskość (Horrocks 1994, s. 25; za: Mizierska 2003, s. 182).

Poglądy Horrocksa są zgodne ze stanowiskiem zajmowanym przez badaczy, którzy w latach 70. i 80. XX wieku w Stanach Zjednoczonych kładli podwaliny pod dziedzinę określaną mianem men's studies. Herb Goldberg i Joseph Pleck krytykowali tradycyjny paradygmat męskości i wskazywali na potrzebę jego zmiany. Goldberg w książce The Hazards of Being Male (1976) ukazuje, jak wiele mężczyzna traci ze swej spontaniczności i wrażliwości, przejmując stereotypową rolę męską. Autor bardzo krytycznie ocenia tradycyjną koncepcję męskości, w której zawarty jest nakaz bycia twardym i nieokazywania własnej słabości, bowiem znacząco ogranicza człowieczeństwo mężczyzny. Amerykański psycholog w pracy zaty-

5 W Stanach Zjednoczonych i w innych krajach działa wiele społecznych ruchów mężczyzn głoszących różne poglądy. W niniejszej pracy konserwatywny, antyfeministyczny i wrogi homoseksualistom ruch mężczyzn będę określał mianem „konserwatywny ruch mężczyzn”, zaś ruch mężczyzn będący spadkobiercą ruchu wyzwolenia kobiet i gejowskiego ruchu wyzwolenia ujmuję pod nazwą "profeministyczny ruch mężczyzn”. 
tułowanej The New Male (1979) ${ }^{6}$ formułuje pogląd, iż tradycyjny paradygmat męskości jest paradygmatem samozniszczenia (Goldberg 2000, s. 13).

Trzeci sposób postrzegania kryzysu męskości wiąże ów kryzys z dyskomfortem odczuwanym przez mężczyzn w związku ze ścieraniem się różnych modeli mężczyzny w kulturze współczesnej. Omawiane podejście dotyczy założenia, że tradycyjny model mężczyzny nie jest, przynajmniej dla części mężczyzn, rozwiązaniem optymalnym, ale nie ma dobrej alternatywy (por. Wojnicka 2010). Élisabeth Badinter wskazuje dwa sprzeczne modele męskości w kulturze współczesnej. W pierwszym modelu, który francuska filozofka nazywa mianem mężczyzny "twardego", określenie tożsamości męskiej odbywa się poprzez następujące reguły: nic kobiecego, bycie zwycięzcą, twarde zasady, poleganie tylko na sobie. Zdaniem Badinter ten model stanowi zagrożenie zarówno dla mężczyzn, jak i dla kobiet, bowiem nie pozwala na zaspakajanie dużej części potrzeb emocjonalnych. Opozycyjnym modelem jest mężczyzna „miękki”, będący zaprzeczeniem pierwszego modelu. Jednak nowy model sprawia, iż część mężczyzn nie jest w stanie przekroczyć granicy oddzielającej dzieciństwo od wieku dojrzałego i nie potrafi wyzwolić się z uzależnienia od swojej matki lub partnerki. Według francuskiej badaczki żaden z opisywanych tu modeli nie wpływa pozytywnie na kondycję mężczyzn (Badinter 1993, s. 118-138, 160-162).

Podobne do Badinter poglądy na temat braku alternatywy dla tradycyjnie pojmowanej męskości głoszą inni autorzy, choć niektórzy w większym stopniu niż francuska badaczka artykułują problem kryzysu męskości. John MacInnes w książce The End of Masculinity (1998) twierdzi, że kryzys męskości jest faktem i występuje powszechnie. Autor pisze o niektórych negatywnych aspektach tradycyjnego modelu męskości i poważnym kryzysie owego modelu, lecz nie znajduje wzorca, który mógłby go zastąpić. Nowy androgyniczny wzorzec określa mianem utopii (McInnes 1998, s. 46). Brytyjski socjolog twierdzi, że we współczesnych zachodnich społeczeństwach cechy, które kiedyś uznawane były za typowe dla mężczyzn, takie jak siła, odwaga, niezależność, hart ducha, inicjatywa seksualna, obecnie coraz częściej służą za punkt wyjścia do ataku na mężczyzn. McInnes uważa, że nie istnieją żadne pozytywne modele ról męskich (Manly Virtues and Masculine Vices; za: Melosik 2002, s. 10-11).

Czwarte stanowisko dostrzega źródła kryzysu męskości w kryzysie heteroseksualizmu i jego hegemonicznej pozycji w kulturze (Melosik 2002, s. 35-47; Skoczylas 2012). Heteroseksualizm stanowi jeden z głównych elementów konstytuujących tradycyjny paradygmat męskości (zob. Arcimowicz 2003, s. 34-36, 56-57). Począwszy od lat 60. XX wieku działania ruchów społecznych gejów i lesbijek w społeczeństwach należących do kręgu kultury euro-amerykańskiej poddały $\mathrm{w}$ wątpliwość heteroseksualność jako jedyną możliwą normę seksualną. Ważną rolę odegrały w tym względzie również prace autorek i autorów łączonych

6 Książka Goldebrga The New Male została przetłumaczona na język polski i ukazała się nakładem Wydawnictwo Bertelsman Media pod mylącym, zapewne ze względów marketingowych, tytułem Wrażliwy macho: mężczyzna 2000. 
ze studiami gejowsko-lesbijskimi, a następnie badania i koncepcje teoretyczne rozwijane w ramach queer studies (zob. Seidman 2006, s. 11-12; Baer, Lizurej 2007, s. 14-15; Corber, Vallocchi 2003, s. 3-4). Od lat 80. XX wieku w filmach i serialach oraz innych przekazach medialnych powstających w krajach należących do kręgu kultury Zachodu zaczęły pojawiać się pozytywne wizerunki osób nienormatywnych seksualnie. Należy jednak dodać, że zmiany stosunku mediów do mniejszości seksualnych nie wynikają jedynie z przemian obyczajowych w zakresie seksualności oraz większej tolerancji wobec ludzi o nienormatywnej orientacji seksualnej, ale także z przyczyn ekonomicznych (zob. Arcimowicz 2013, s. 144-148, 409-428; Leo 2001, s. 101-123; Tropiano 2002, s. 109-128; Melosik 2002, s. 35-47). Badania przeprowadzone w Stanach Zjednoczonych i w Polsce pokazują, że osoby nienormatywnie seksualnie stanowią kilka procent społeczeństwa. Wśród nieheteroseksualnych mężczyzn większy jest odsetek osób osiągających ponadprzeciętne dochody i mających wyższe wykształcenie niż wśród heteroseksualistów (por. Solomon 2006, s. 183; Izdebski 2012, s. 386-388). Reklamodawcy i nadawcy przekazów medialnych, w dobie zaostrzającej się konkurencji, muszą ten fakt brać pod uwagę, dlatego coraz więcej przekazów kierują do osób nienormatywnych seksualnie.

Warto w tym miejscu przywołać myśl Anthony'ego Giddensa (2006), który zauważa, że jedną z przyczyn osłabienia heteroseksualizmu jako jedynej akceptowanej normy jest oddzielenie seksu od jego funkcji prokreacyjnej. Rewolucja seksualna i upowszechnienie środków antykoncepcyjnych otworzyły przed osobami heteroseksualnymi możliwości, które dawniej miały tylko osoby homoseksualne (zob. Skoczylas 2012). Ponadto należy wspomnieć, iż sama kategoria orientacji seksualnej może tracić na znaczeniu. Lepsze rozpoznanie ludzkiej seksualności doprowadziło bowiem do odkrycia takich kategorii, jak aseksualizm i autoseksualizm.

Zmniejszenie się normatywnych wpływów orientacji heteroseksualnej prowadzi do kryzysu męskości, ponieważ tradycyjne tożsamości genderowe i seksualne muszą być zawsze binarne: męskość versus kobiecość, heteroseksualność versus homoseksualność (Traister 2000, s. 293; za: Skoczylas 2012).

Piąte podejście łączy kryzys męskości z globalnym kryzysem świata. Zdaniem austriackiego fizyka i filozofa Fritjofa Capry (1987) w ostatnim dwudziestoleciu XX wieku świat znalazł się w stanie głębokiego, globalnego kryzysu. Autor Punktu zwrotnego pisze: „Złożony, wielowymiarowy kryzys ogarnął wszystkie aspekty naszego życia - zdrowie i warunki życia, jakość środowiska i stosunki społeczne, gospodarkę, technologię i politykę. Skala i ostrość tego kryzysu nie mają precedensu w dziejach ludzkości" (Capra 1987, s. 43). Autor ten uważa, iż ustalenie przyczyn obecnego kryzysu cywilizacji jest niemożliwe, jeżeli patrzy się nań wycinkowo, a przy takim postrzeganiu rzeczywistości trwa większość uczonych, co uniemożliwia im zrozumienie najpoważniejszych problemów naszych czasów. Problemy te mają charakter systemowy, a to oznacza, że wszystkie są ze sobą ściśle powiązane i wzajemnie od siebie zależne. Według austriackiego filozofa zjawiskiem o najgłębszym znaczeniu dla zmiany systemu społecznego, gospodarczego i politycz- 
nego jest niespieszny i oporny, ale nieuchronny schyłek patriarchatu. Zdaniem Capry i innych autorów należy wyzwolić naukę z elementu dominacji człowieka nad przyrodą, wyrażającego stosunek antropocentryczny i androcentryczny (por. Capra, Steindl-Rast, Matus 1991). Capra sygnalizuje sprzężenie zwrotne między patriarchatem i globalnym kryzysem współczesnego świata, wychodząc z założenia, iż androcentryzm jest owego kryzysu przyczyną, a wyjście z kryzysu może się odbyć jedynie na skutek zmiany tradycyjnego paradygmatu męskości i przyznania większej roli kobietom w budowie nowego porządku społecznego. Stanowisko austriackiego uczonego jest blisko związane z refleksją nad kondycją świata wyrażaną w ruchu New Age.

W szóstym podejściu przyjmuje się, że kryzys męskości to w o wiele większym stopniu wytwór dyskursu niż realny problem społeczny związany z problemami tożsamościowymi i psychicznymi współczesnych mężczyzn. Według części autorek i autorów dyskursywnie konstruowany kryzys męskości nie jest zjawiskiem nowym, a ów dyskurs nasila się w momentach, kiedy tradycyjny porządek genderowy wydaje się być szczególnie zagrożony. Kulturoznawczyni Elahe Haschemi Yekani (2011, s. 9) zwraca uwagę, że opłakiwanie domniemanego kryzysu męskości wydaje się cyklicznie powracającym zdarzeniem. Tezę tę potwierdzają badania Michaela Messnera, autorytetu w dziedzinie men's studies. Amerykański socjolog twierdzi, że utyskiwania nad słabnącą tradycyjną męskością pojawiły się w USA już na przełomie XIX i XX wieku ${ }^{7}$. Było to związane z feminizmem pierwszej fali. Działania Amerykanek doprowadziły do pewnych zmian w prawie: uniezależnienia kobiet od męskich opiekunów, reformy systemu edukacji umożliwiającej dziewczynkom zdobywanie wykształcenia. Zmiany te wielu mężczyzn zaczęło postrzegać, jako zagrożenie swojej dominującej pozycji. W debacie publicznej krytykowano większą obecność kobiet na rynku pracy i edukacji, obawiano się, że przemiany spowodują feminizację społeczeństwa. W związku z tym w 1910 roku powołano do życia skauting (The Boys Scout of America), który miał zadbać o to, by „prawdziwi mężczyźni” mogli zaszczepiać chłopcom „prawdziwą męskość". Najważniejszą dyscypliną sportu w USA uczyniono futbol amerykański, sport brutalny i urazowy, który miał stanowić symbol męskiej siły i władzy (Messner 1994, s. 102-114). Można zatem powiedzieć, iż opisywany przez Faludi backlash, będący w latach 80 . XX wieku reakcją konserwatywnych mężczyzn na osiągnięcia feminizmu drugiej fali, pojawił się znacznie wcześniej.

Siódme stanowisko jest reprezentowane przez autorki i autorów, którzy uważają, iż kryzysu męskości nie ma. Omawiane podejście często przenika się ze stanowiskiem, w którym akcentuje się dyskursywną konstrukcję kryzysu męskości. Badaczki i badacze poddający w wątpliwość sensowność operowania terminem „kryzys męskości” piszą o poszerzeniu pojęcia lub definicji męskości (Gardiner 2014; Duch-Dyngosz 2013a, 2013b). W nowej wizji mężczyzny mieszczą się wzorce

7 Badinter pisze o francuskim i angielskim kryzysie męskości w XVII i XVIII wieku. Francuska badaczka ma na myśli pojawienie się „wykwintnisiów”, czyli mężczyzn stosujących makijaż, noszących rajstopy i buty z klamerkami oraz peruki, mówiących z emfazą (Badinter 1993, s. 29-32). 
zachowań łączące się z przekraczaniem przez mężczyzn tradycyjnego binaryzmu genderowego - na przykład wzorzec opiekuna dziecka czy wrażliwego partnera kobiety. Zdaniem zespołu naukowców z sześciu krajów (Austrii, Bułgarii, Hiszpanii, Niemiec, Norwegii i Izraela) łączenie tożsamości męskiej głównie z pracą zawodową (work based gender) podlega obecnie ewolucji, aż do męskości opartej na trosce o innych (carring masculinity) i aktywnym udziale w codziennych czynnościach domowych (Puchert, Gärtner, Höyong 2005; za: Kwiatkowska, Nowakowska 2006, s. 17).

\section{Kryzys męskości czy szansa dla mężczyzn?}

W tym miejscu chciałbym zaprezentować własne stanowisko dotyczące kryzysu męskości. Sądzę, iż nie można używać pojęcia kryzysu męskości en bloc w odniesieniu do wszystkich wzorców zachowań mężczyzn funkcjonujących w kulturze współczesnej. Jeśli miałbym posłużyć się określeniem „kryzys męskości”, to $\mathrm{w}$ odniesieniu do patriarchalnego paradygmatu mężczyzny, choć i w tym przypadku wolałbym raczej termin „przemiany męskości”.

Moim zdaniem ważne jest i jak najbardziej pozytywne, że obok tradycyjnego paradygmatu męskości w niektórych krajach wyrosły, a w niektórych - jak w Polsce - dopiero kiełkują, nowe wzorce męskości ${ }^{8}$. Męskość może mieć wiele obliczy i mężczyźni mogą swoją tożsamość budować, biorąc pod uwagę różne wartości. Pojawienie się nowych modeli męskości stwarza możliwość wyboru, współdziałania, pozwala na eksponowanie cech tradycyjnie uważanych za męskie jak i kobiecych, a w pewnych sytuacjach pozwala osiągnąć pełnię indywidualnego potencjału człowieka.

Zasadniczo zgadzam się ze stanowiskiem reprezentowanym przez autorki i autorów, którzy uważają, iż kryzys męskości jest w największym stopniu konstruktem dyskursywnym. Nie neguję, że część mężczyzn w związku z przemianami społecznymi i emancypacją kobiet może mieć problemy z określeniem swojej tożsamości i odnalezieniem się w nowych rolach, co potwierdzają niektóre badania (zob. Species. Praktyczny przewodnik po świecie młodych mężczyzn 2008, s. 6-25). Jednak więcej problemów, choć często nieuświadomionych, przysparza mężczyznom patriarchalny paradygmat męskości (zob. Friedan 1993, s. 173-180; Chmura-Rutkowska, Ostrouch 2007, s. 277-286). To, co jednym wydaje się kryzysem może stanowić szansę dla innych, mam na myśli heteroseksualne kobiety i heteroseksualnych mężczyzn odrzucających patriarchalną wizję męskości, osoby nienormatywne seksualnie i/lub płciowo. Gdy spojrzymy na przemiany kategorii męskości z szerszej perspektywy, możemy skonstatować, że odrzucenie patriar-

8 O coraz większej sile nowego paradygmatu męskości świadczy nie tylko coraz powszechniejsze uczestnictwo mężczyzn w opiece nad dzieckiem i obowiązkach domowych, ale też pojawienie się profeministycznych ruchów mężczyzn, które są widoczne w Ameryce Północnej i niektórych krajach europejskich (zob. Śmietana 2006; Wojnicka 2010). 
chalnego paradygmatu męskości opartego na wartościach, takich jak dominacja, władza, ujednolicenie, może być początkiem budowy nowego ładu społecznego, w którym - bardziej niż obecnie - będzie się cenić sprawiedliwość, wolność i różnorodność. Poszukiwanie jednej wielkiej alternatywy dla patriarchalnego paradygmatu męskości nie jest dobrym rozwiązaniem, gdyż dostrzegam w tym niebezpieczeństwo zastąpienia jednej hegemonii jakąś inną hegemonią. Uważam, że nie należy szukać na siłę alternatywy dla tradycyjnego modelu męskości, wystarczy nie przeszkadzać w rozwijaniu nowych wzorców męskości.

Obrońcy patriarchalnego ładu społecznego uważają, że podział na sferę rodzinną zdominowaną przez kobiety i publiczną zdominowaną przez mężczyzn jest stanem naturalnym i nie należy tego zmieniać. Kłóci się to z prawem każdego człowieka do podejmowania decyzji dotyczącej jego życia, która powinna mieć wyższą wartość niż kulturowy przymus narzucający wszystkim ludziom jednakowe zachowania związane z płcią. Należy zauważyć, że społeczeństwa zachodnie zaczęły się rozwijać najszybciej, gdy kobiety uzyskały prawa podobne do mężczyzn, zaczęły się kształcić i pracować poza domem. Nie jest dobrze, kiedy określenie przez jednostkę drogi życiowej jest wynikiem presji ideologicznej i przymusu prawnego. Demokracja nie polega na narzucaniu unifikacji, lecz na tworzeniu warunków do realizowania przez jednostki różnych wzorów osobowych. Nie ma jednej ahistorycznej, uniwersalnej męskości, męskości jest wiele. Potencjalnie w konkretnym społeczeństwie może istnieć obok siebie wiele równoprawnych, ale różnych koncepcji mężczyzny.

\section{Refleksje końcowe}

Należy zdawać sobie sprawę, że najważniejsze publikacje poświęcone kategorii męskości dotyczą głównie zachodnich społeczeństw, a ich autorki i autorzy najczęściej analizują męskość w kontekście własnej kultury. Większość anglojęzycznej literatury na temat mężczyzn ma wyraźny rys etnocentryczny i/lub klasowy. Raewyn Connell uważa, że dyskurs dotyczący męskości konstruowany jest na podstawie życia kilku procent populacji mężczyzn, w jednym obszarze kulturowym i jednym okresie historycznym (Connell 1993, s. 600). Zwolennicy esencjalizmu biologicznego, ale również bardziej postępowi autorzy, nierzadko zapominają o dużym zróżnicowaniu męskości w poszczególnych kulturach świata. Wielu autorów zapomina również o tym, że, jakkolwiek by to dziwnie nie zabrzmiało, patriarchat w dziejach ludzkości jest stosunkowo młodym systemem społecznym. Odkrycia archeologiczne oraz badania prowadzone przez przedstawicielki i przedstawicieli innych dyscyplin naukowych wskazują, że w okresie młodszego paleolitu i neolitu, a więc między czterdziestym tysiącleciem a trzecim tysiącleciem przed Chrystusem, istniały społeczeństwa egalitarne, a nawet takie, w których dominującą rolę odgrywały kobiety (Cameron 1981; Gimbutas 1987; Campbell 1994; Brach-Czaina 1997; Krzak 1994, 2007; Bachofen 2007). 
Według Lindy Brannon współcześnie możemy wyróżnić trzy kategorie opisujące mężczyzn i ich reakcje na zmiany kobiecych ról. Pierwszą kategorię stanowią mężczyźni tradycyjni, ubolewający nad zmianami, niewidzący dla siebie żadnych korzyści z emancypacji kobiet, uważający kobiety za rywalki. Drugą grupę tworzą mężczyźni w okresie przejściowym, którzy są zdolni do interakcji z kobietą jako partnerką w związku intymnym. Mężczyźni ci nie zawsze popierają emancypacyjne dążenia kobiet, ale starają się dostosować do zmian w kobiecych rolach, zmieniając swoje zachowania. Trzecia kategoria obejmuje mężczyzn postępowych, popierających ruch feministyczny, a zwłaszcza koncepcję, że tradycyjna rola płciowa jest dla mężczyzn szkodliwa (Brannon 2002, s. 554-555). Jak pokazuje historia, już w XIX wieku całkiem liczna grupa mężczyzn - również znanych osobistości - wspierała żądania wysuwane przez sufrażystki (Brod 1987, s. 269; Shiffman 1987, s. 295). Ale zarówno w przeszłości, jak i dzisiaj profeminiści są mniejszością.

W dyskusji na temat kryzysu męskości często podkreśla się, jak słabi są mężczyźni, że już niewiele albo nic od nich nie zależy. Ale kiedy sprawdzimy, kto posiada realną władzę, kto podejmuje najważniejsze decyzje, okazuje się, że dysproporcja władzy mężczyzn i kobiet - na korzyść tych pierwszych - nadal jest duża. Należy również pamiętać o tym, że zniesienie dyskryminacji płciowej de iure nie oznacza automatycznie rzeczywistej równości kobiet i mężczyzn we wszystkich obszarach życia. Jest to pewien proces stymulowany przez rozwiązania prawne, ale należy zdawać sobie sprawę z tego, że nie gwarantują one jego całkowitego powodzenia.

Uważam, iż pojawienie się nowych wzorów męskości stwarza szansę uwolnienia się spod presji tradycyjnego paradygmatu łączącego męskość z dominacją i przemocą. Nie chodzi o wytworzenie presji kulturowej nakazującej mężczyznom realizowanie nowych wzorów, lecz o wskazywanie niedostatków dotychczasowego modelu socjalizacji płciowej i stworzenie możliwości równoprawnego funkcjonowania różnych wzorców męskości. W naszym kraju istnieją dynamiczne napięcia między tradycyjnymi wzorami genderowymi a nowymi. Podejmowane są próby zahamowania przemian, jednak ewolucji nie da się zatrzymać, można ją co najwyżej nieco spowolnić.

\section{Literatura:}

Arcimowicz K., 2013, Dyskursy o ptci i rodzinie w polskich telesagach. Analiza seriali obyczajowych najpopularniejszych na początku XXI wieku, Wydawnictwo Akademickie ŻAK, Warszawa.

Arcimowicz K., 2003, Obraz mężczyzny w polskich mediach. Prawda, fałsz, stereotyp, Gdańskie Wydawnictwo Psychologiczne, Gdańsk.

Bachofen J. J., 2007, Matriarchat. Studium na temat ginajkokracji świata starożytnego podtug natury religijnej i prawnej, Wydawnictwo $\mathrm{KR}$, Warszawa.

Badiner E., 1993, XY: Tożsamość mężczyzny, W.A.B., Warszawa. 
Baer M., Lizurej M., 2007, Z odmiennej perspektywy. Pomiędzy studiami gejowsko-lesbijskimi a studiami queer. Wprowadzenie [w:] M. Baer, M. Lizurej (red.), Z odmiennej perspektywy. Studia queer w Polsce, Oficyna Wydawnicza Arboretum, Wrocław.

Bem S., 2000, Męskość kobiecość: o różnicach wynikających z ptci, Gdańskie Wydawnictwo Psychologiczne, Gdańsk.

Bly R., 1993, Żelazny Jan: rzecz o mężczyznach, Dom Wydawniczy Rebis, Poznań.

Brach-Czaina J., 1997, Bogini. Neolityczne zabytki Malty i Gozo [w:] J. Brach-Czaina (red.), Od kobiety do mężczyzny i z powrotem: rozważania o ptci w kulturze, Wydawnictwo Trans $\mathrm{Hu}$ mana, Białystok.

Brannon L., 2002, Psychologia rodzaju, Gdańskie Wydawnictwo Psychologiczne, Gdańsk.

Brod H., 1987, A Case for Men's Studies [w:] M.S. Kimmel (red.), Changing Men: New Directions in Research on Men and Masculinity, Sage Publications, Newbury Park.

Cameron D.O., 1981, Symbols of Birth and Death In the Neolithic Era, Kenyon-Deane, London.

Campbell J., 1994, Potęga mitu, Znak, Kraków.

Capra F., 1987, Punkt zwrotny: nauka, społeczeństwo, nowa Kultura, Państwowy Instytut Wydawniczy, Warszawa.

Capra F., Steindl-Rast D., Matus T., 1995, Należeć do wszechświata: poszukiwania na pograniczu nauki i duchowości, Wydawnictwo Znak, Kraków.

Chmura-Rutkowska I., Ostrouch J., 2007, Mężczyźni na przełęczy życia. Studium socjopedagogiczne, Impuls, Kraków.

Connell R.W., 1995, Masculinities, Policy Press, Cambridge.

Connell R.W., 1993, The Big Picture. Masculinity in Recent World History , "Theory and Society” No. 5.

Corber R.J., Valocchi S., 2003, Introduction [w:] R.J. Corber, S. Valochi (red.), Queer Studies. An Interdysciplinary Reader, Blackwell Publishing, Malden-Oxford-Melbourne.

Crabb L., 1994, Mężczyźni i kobiety. O tym jak się cieszyć tym co nas różni, Wydawnictwo Rodzinny Krąg, Warszawa.

Dobson J., 1994, Co każdy mąż chciałby aby jego żona wiedziała o mężczyźnie, Oficyna Wydawnicza Vocatio, Warszawa.

Duch-Dyngosz M., 2013, Atlas polskich mężczyzn, „Znak” nr 11.

Duch-Dyngosz M., 2013, Kryzys męskości to mit!, portal: Onet.pl, 7.11 .2013 r., http://facet. onet.pl/kryzys-meskosci-to-mit/wvyzj [dostęp: 5.03.2014].

Faludi S., 1992, Backlash. The Undeclared War Against American Women, Vintage, London.

Friedan B., 1993, The Fountain of Age, A Touchstone Book, New York.

Gardiner E., 2014, There's No Crisis in Masculinity, Only a Narrow Definition of Men, portal: The Conversation, 31.01.2014 r., http://theconversation.com/theres-no-crisis-in-masculinity-only-a-narrow-definition-of-men-21777 [dostęp: 13.10.2014].

Giddens A., 2006, Przemiany intymności. Seksualność, miłość i erotyzm we wspótczesnych społeczeństwach, Wydawnictwo Naukowe PWN, Warszawa.

Gimbutas M., 1989, The Language of the Goddes, Harper and Row, New York.

Goldberg H., 1976, The hazards of being male, Signet, New York.

Goldberg H., 2000, Wrażliwy macho: mężczyzna 2000, Wydawnictwo Bertelsman Media, Warszawa.

Haschemi Yekani E., 2011, The Privilege of Crisis, Narratives of Masculinities in Colonial and Postcolonial Literature, Photography and Film, Campus, Frankfurt.

Horrocks R., 1994, Masculinity in Crisis, Houndmills, Basingstoke. 
Izdebski Z., 2012, Seksualność Polaków na początku XXI wieku. Studium badawcze, Wydawnictwo UJ, Kraków.

Krzak Z., 1994, Megality Europy, Wydawnictwo Naukowe PWN, Warszawa.

Krzak Z., 2007, Od patriarchatu do matriarchatu, Wydawnictwo Trio, Warszawa.

Kwiatkowska A., Nowakowska A., 2006, Mężczyzna polski. Psychospołeczne czynniki warunkujące petnienie ról zawodowych i rodzinnych, Wydawnictwo Wyższej Szkoły Ekonomicznej, Białystok.

Leo J.R., 2001, Reprezentacje gejów w amerykańskim melodramacie telewizyjnym lat 80. [w:] E. Ostrowska (red.), Gender - Film - Media, Wydawnictwo Rabid, Kraków.

Malinowska E., 2002, Feminizm europejski: demokracja parytetowa a polski ruch kobiet. Socjologiczna analiza walki o równouprawnienie ptci, Wydawnictwo Uniwersytetu Łódzkiego, Łódź.

McInness J., 1998, The End of Masculinity. The Confusion of Sexual Genesis nad Sexual Difference in Modern Society, Open University Press, Ballmoor.

Melosik Z., 2002, Kryzys męskości w kulturze wspótczesnej, Wolumin, Poznań.

Messner M.A., 1994, Boyhood, Organized Sports, and the Construction of Masculinities [w:] M.S. Kimmel, M.A. Messner (red.), Men's Lives, Allyn and Bacon, Boston.

Mizierska E., 2003, Pogrążony w kryzysie. Portret mężczyzny w polskim kinie postkomunistycznym, „Kwartalnik Filmowy” nr 43.

Petrey-Mroczkowska J., 1998, Promise Keepers, czyli rehabilitacja ojcostwa, „Więź” nr 5.

Puchert R., Gärtner M., Höyong S., 2005, Work Changes Gender. Men and Equality in the Transistion of Labour Forms, Barbara Budrich Publishers, Leverkusen-Opladen.

Seidman S., 1996, Introduction [w:] S. Seidman (red.), Queer Theory/Sociology, Blackwell Publishers, Cambridge.

Shiffman M., 1987, The Men's Movement [w:] M.S. Kimmel (red.), Changing Men: New Directions in Research on Men and Masculinity, Sage Publications, Newbury Park.

Skoczylas Ł., 2012, Kryzys męskości. Ujęcia teoretyczne, wortal: „Kultura i Historia”, http://www.kulturaihistoria.umcs.lublin.pl/archives/4250 [dostęp: 13.10.2014].

Solomon M.R., 2006, Zachowania i zwyczaje konsumentów, tłum. J. Sugiero, Helion, Gliwice.

Species. Praktyczny przewodnik po świecie młodych mężczyzn, 2008, Discovery Communication Europe Ltd, London.

Śmietana M., 2006, Ruchy społeczne mężczyzn na tle studiów nad męskością [w:] A. Lipowska-Teutsch (red.), Mężczyźni na rzecz zmiany, Towarzystwo Interwencji Kryzysowej, Kraków.

Traister B., 2000, Academic Viagra: The Rise of American Masculinity Studies, „American Quarterly" Vol. 52, No. 2.

Tropiano S., 2002, The Prime Time Closet. A History of Gays and Lesbians on TV, Applause Theatre and Cinema, Books, New York.

Walby S., 1990, Theorizing Patriarchy, Blackwell, Oxford.

Wojnicka K., 2010, Od maskulinizmu do profeminizmu. Społeczne ruchy mężczyzn - zarys problematyki, „UniGender" nr 1: http://www.unigender.org/?page=biezacy\&issue=04\&article $=04$ [dostęp: 10.03.2014]. 


\section{Summary}

The crisis of masculinity or opportunity for men: a critical overview

In this article the author provides a critical overview of the debates around the status of men. The ways in which these kinds of problematics have emerged are discussed at length to highlight the kind of polemic which continues to inform the moral panic surrounding the plight of men who have acquired the status of the 'new disadvantaged'.

\section{Keywords}

masculinities, crisis, progress, change, social research

\section{Słowa kluczowe}

męskości, kryzys, postęp, zmiana, badania społeczne 
